\title{
The value of problem-based learning in learning for sustainability: undergraduate accounting student perspectives
}

\section{Journal of Accounting Education (Elsevier)}

Corresponding author: Dr. Lynne Wyness, 3 Endsleigh Place, Drake Circus, Plymouth, PL4 8AA, 01752587626 lynne.wyness@plymouth.ac.uk

Pedagogic Research Institute and Observatory (PedRIO), University of Plymouth

Co-author: Fiona Dalton, Cookworthy, fiona.dalton@plymouth.ac.uk

Accepted: 18/09/2018

\begin{abstract}
This paper discusses the findings of a small ethnographic study that explored students' perceptions of the value of problem-based learning in introducing sustainability, in a two semester elective accounting module at a post-1992 university in south-west England.
\end{abstract} Findings suggest that students believed that gaining knowledge of sustainability is essential for all accounting undergraduates, not just those who elect to follow a specialist module, and that problem-based learning is an appropriate and enabling method with which to introduce sustainability. It is also important for developing individual interest, building knowledge of various accounting, auditing, and reporting procedures, and motivating students. For those who wish to develop a sustainability in accounting module, a caveat is presented that delivery of sustainability within a core, single-semester module has potential implications for student motivation and depth of learning. Recommendations are made to help mitigate these potential issues and with the necessary amendments in place, the paper argues that sustainability should constitute a core module in all accounting programmes in the interests of students, the accounting profession, and society at large.

Keywords:

Sustainability

Problem-based learning

Group work

Ethnographic methods 


\section{Introduction}

It has been well-documented that higher education (HE) programmes in the second decade of the $21^{\text {st }}$ century need to prepare undergraduate students to live, work, and thrive in an uncertain and risky world that demands students develop both knowledge and competencies in sustainability (HEFCE, 2005; Dawe, Jucker, R. \& Martin, S. 2005; Jones,

Selby, \& Sterling, 2010). This educative endeavour has gathered urgency in recent years and sustainable and ethical practices are of increasing concern to professions like law and accountancy. Indeed, the inclusion of sustainability in undergraduate accountancy programmes has been the topic of much discussion over the past twenty years (Bebbington, 1997; Dyball \& Thompson, 2013; Coulson \& Thomson, 2006; Thomson \& Bebbington, 2004; Gray \& Collison, 2002; Kelly \& Alam, 2009; Hazleton \& Haigh, 2010; Gray, 2013; Botes, Low, \& Chapman, 2014; Sharma \& Kelly, 2014; Lee, Birkey, \& Patten, 2016. However, considerable disparity exists between the extent to which sustainability has been 'embedded' in accounting programmes across the world, with Australia perhaps leading the way with a comprehensive review of its degree programmes and modules, and coverage of sustainability, and a more mixed picture prevalent in the UK (see Dean, Perkiss, Misic, \& Luzia, 2018, for example). In the academic literature, attention has been given to how to include sustainability in an undergraduate accounting module but the search for pedagogies that facilitate both knowledge acquisition and skill development continues.

This paper discusses the findings of a research project that considered the value of problem-based learning in introducing sustainability in a third year elective accounting module, Accounting for Sustainability, at a modern, post-1992 university in south-west England. The project focused on two core research questions; firstly what are students' perspectives on the importance of learning about sustainability in their undergraduate Accounting degree programme, and secondly, how valuable do students perceive problembased learning (PBL) to be as a vehicle for learning about sustainability? Two key points are made in this paper. Firstly, it is proposed that gaining knowledge of sustainability is essential for all accounting undergraduates, not just those who elect to follow a specialist module, and this paper lends weight to a growing body of evidence that shows that accounting for sustainability should take a far more prominent place in mainstream accounting education. Secondly, the literature in Sustainability Education argues that pedagogies for sustainability need to be active, real-world based, collaborative, and critical (Jones et al, 2010; Ryan \& 
Cotton, 2011). Pedagogies of accounting for sustainability have been discussed by some scholars (Coulson \& Thomson, 2006; Thomson \& Bebbington, 2004; Gray \& Collison, 2002) and include dialogic, transcendent, and critical thinking pedagogies. This paper proposes that problem-based learning is a suitable method by which to introduce sustainability to accounting students and presents a structured primer on how it could be used by other HE providers. Originally developed in a Canadian medical school in the 1960s, and favoured within health professions and vocational education since, problem-based learning (PBL) is an active and structured pedagogical approach that places the student at the centre of the learning process, presenting scenarios and problems for groups to research and present suitable solutions. This paper presents evidence that students perceive the value of employing PBL in order to develop their research and problem-solving skills, build knowledge of various accounting, auditing, and reporting procedures, and motivating them to learn the subject matter to solve problems.

The following section presents a literature review that examines the potential for PBL in teaching for sustainability in accounting programmes. The next section provides the methodology and parameters of this study, followed by a discussion of the results in relation to the key literature. The paper concludes with key thoughts and recommendations for other Higher Education providers of accounting education.

\section{Literature review}

Since the 1980s, an enduring focus of the work of academics and practitioners within the fields of environmental education (EE) and Education for Sustainable Development (ESD) has been how education systems might prepare learners to understand, engage in, and promote more sustainable forms of social, environmental, and economic processes. Momentum gathered after the Brundtland report (1987), and the scope of sustainability began to widen to all education, including higher education and degree programmes. Some accounting educators recognised that the need for change within the wider accounting profession could come about through a change within the training and educating of accounting students; Day $(1995,104)$ argued that 'the possibilities of changing accounting practices depend just as much on transforming current generations of accounting students' understandings, as on transforming current practitioners, and their understanding.'

The critique of traditional accounting programmes began in earnest in the mid-1990s, indicative of the nascent acknowledgement of the need for more sustainable ways of working. 
McPhail \& Gray (1996) noted that students in other disciplines appeared to have greater ethical awareness than accounting students, and questioned the practice of accounting education that effectively constructed an ethical vacuum in which students prepared to enter the profession. In a rather damning account of accounting education at this time, they suggested that 'the way in which accounting is conceived, constructed and taught makes it inevitable that accounting students will experience intellectual and moral atrophy' (McPhail $\&$ Gray, 1996, 3). In addition, the solely vocational focus of late $20^{\text {th }}$ century accounting programmes on skill and technique acquisition, 'plants the seeds for a lack of ethical maturity which may, at least in part, be linked to ethical failures of practising accountants' (after Gray et al, 1994, in Bebbington, 1997, 372). Bebbington (1997) contended that adopting Environmental Accounting (EA) into the general accounting curriculum would enable staff and learners to question and rethink their ethical accounting stance, and challenge students' perceptions of themselves as future accountants. According to a survey conducted at the time by Owen, Humphrey, \& Lewis (1994), very few British accounting academics believed EA warranted a place in the accounting curriculum.

Accounting education has undergone substantial changes over the past two decades since that early critique. Gray $(2013,309)$ charts the trajectory of scholars who have witnessed the rise of sustainability accounting from being a 'tolerated, [to] even a welcome, guest within many schools' but still highlights the dearth of literature that connects accounting education and sustainability in a creative, challenging, and productive way. Sustainability has taken different guises in accounting education, where Social and Environmental Accounting (SEA) has played a dual role in both critiquing existing practices of traditional accounting and thinking creatively about the future of accounting and its potential to play a role in re-creating a more sustainable society (Bebbington, 1997). Gray \& Collison (2002) raise key questions about the nature of education, the environment, and accounting itself (client driven or an independent force for societal progression), which they say need to be addressed before sustainability can be integrated into a curriculum. The way in which sustainability is included in the traditional accounting curriculum depends, they say, on one's perspective on the purpose of education; whether it is primarily to enable graduates to secure professional employment or to serve civil society. The latter entails a more transcendent or dialogic education (Coulson \& Thomson, 2006); this emancipatory flavour has also been picked up by Thomson \& Bebbington (2004), where they draw on Paulo Freire's principles of critical pedagogy to assess the educative process of generating social 
and environmental reporting. This perspective views education as a process that facilitates the critique of societal norms. Others have proposed a more utopic accounting education that is both disruptive and constructive, 'praxis-grounded and passion driven' (Contrafatto, 2013, $339)$.

Like many disciplines, accounting has experienced tension between the traditional aim of curriculum - the 'cherished cargo of technical content' (Hazleton \& Haigh, 2010: 172) - and the more recent call for universities to develop the skills, attributes, and values ascribed to the graduate accountant. This tension forms the heart of the graduate attributes debate, but many consider that the professional body (such as the Institute of Chartered Accountants in England and Wales (ICAEW), the Association of Chartered Certified Accountants (ACCA) and the Chartered Institute of Management Accountants (CIMA) in the UK) retains the power to loosen its grip on content. The incorporation of sustainability into the whole accounting curriculum still lies within the professional body's power and there has been a call for its approach to sustainability and ethics education to 'shift from relative indifference to strong support or even prescription' (ibid). However, despite 'impassioned pleas, reasoned arguments and inspirations for change', ethical and sustainable forms of accounting education are still too often taught in many universities by pockets of enthusiastic teaching staff, in elective and not core modules (Dyball \& Thomson, 2013, 303). It should be noted that accounting is no different to many other subjects in HE; embedding sustainability in any comprehensive way into degree programmes has been consistently wrought with obstacles, as Ryan \& Tilbury (2013) describe.

In alignment with these debates around the importance of a more transcendent form of accounting education, this paper is premised on the normative approach that society will be better served by more sustainable forms of accounting, reporting, and auditing. To these ends, a pedagogy must be selected that, whilst mindful of the contemporary pre-occupation with employability and 'work-ready' graduates, seeks to expose students to the more emancipatory and enabling style of education as proposed by Thomson \& Bebbington (2004). Students must be exposed to real-life problems, encouraged to dialogue with their peers, critique current practices, and envision solutions that capture passionate and potentially utopic visions of the future. This paper proposes that problem-based learning is the enabling pedagogy that can best facilitate all of these factors.

\subsection{Problem-based learning in sustainability and accounting education in higher education}


Whilst acknowledging that 'no single theory of teaching and learning can fully represent the complexity of learning in PBL' (Gewurtz, Coman, Dhillon, Jung, \& Solomon, 2016, 66), and that the core principles of PBL emerge from a rich genealogy of learning theories (Dochy, Segers, Bossche, \& Gijbels, 2003), the design and delivery of PBL within the module in this study is broadly informed by two pillars of learning theory - social constructivism (Vygotsky, 1978) and cognitivist constructivism (Bruner, 1960; Piaget, 1971; Bloom, Engelhart, Furst, Hill, \& Krathwohl, 1956). Drawing on the social constructivist perspective, PBL is premised on the concept that people learn socially, building on their prior knowledge and making sense of new information through collaborative elaboration and questioning. PBL entails students working collaboratively in small groups to solve complex and challenging problems, and encourages a deeper understanding of an issue or problem, through the application of research, prior knowledge, and the production of a 'solution' that may take various forms (e.g. report, presentation, Wiki, leaflet, website, or another disciplinespecific product). Emphasis is placed on developing students' abilities to solve problems through a clearly-defined PBL process in self-organising small groups. This socially constructed understanding of PBL leans towards a particular assessment design - in the case of this module, $60 \%$ of the final assessment was on a reflective essay that focused on the individual's experience of working in a group to solve the various problems presented. The second theoretical underpinning of the use of PBL in this module comes from the cognitivist perspective. Here, individual thinking about the problem, and its integration into previously assimilated knowledge and experience, is a key part of the learning process. Learning occurs effectively when imitated skills become mastered skills, and Bruner (1978) proposed the concept of 'scaffolding' that structured learning into manageable steps that built on previous knowledge and paved the way for new knowledge to be identified, acquired, and applied to practice. This PBL process utilises the Maastricht seven step approach to provide learners with a methodical stepped approach to acquiring the optimum 'problem-solving' acumen (see Appendix 3). Individual skills and attributes are developed, including critical thinking, the application of theory to practice, team working, communication, report-writing, and reflection.

The focus of this paper considers students' perceptions of the use of PBL as an appropriate pedagogy for learning for sustainability in accounting education and there are a number of papers describing problem-based learning (PBL) approaches to sustainability in a range of subjects; for example, clothing and textile design (Gam \& Banning, 2011), urban 
development (Steinemann, 2003), and engineering (Lehmann, Christensen, Du, \& Thrane, 2008). In an important paper on the expediency of PBL in the pedagogical portfolio of sustainability educators, Thomas (2009) believes that PBL is a key pedagogical device in the drive towards the transformative education needed for sustainability, which requires the wholesale re-orientation of teaching and learning practices toward 'open-ended, real life and purposive enquiry' (Thomas \& Sterling, 2006, in Thomas, 2009, 251). Wicked issues (a term coined by Horst Rittel, but latterly harnessed by sustainability proponents) are societal problems that are not 'wicked' per se, but resilient to being solved, and are complex, ambiguous, uncertain, and interconnected with many issues. Much has been discussed on the nature of the wicked issues, such as climate change, and Brundiers \& Wiek (2013) suggest that these real-world and relevant problems lend themselves to exploration in PBL. Here, emphasis lies with the problem-solving skills and the collaborative skills and conflict resolution skills engendered by working in small groups is generally overlooked.

Literature relating to specific pedagogical approaches is rare in accounting education literature; Apostolou et al (2017) found just 27 articles relating to curricular issues over a twenty-year period in six key accounting education journals. Specifically, PBL in accounting education has received minimal attention. A couple of early papers by Johnstone \& Biggs (1998) and Breton (1999) explored the potential of PBL in accounting education; the former highlighting the need for students to have acquired a certain level of technical knowledge and the latter finding some evidence to suggest that PBL brought about better academic results than traditional forms of accounting education. More recently, Stanley and Marsden (2012) highlight a dearth in the literature, despite calls for over twenty years for a diversification of teaching approaches and a shift from didactic, content-heavy lecturing. There has been limited recognition of the importance of building problem-solving abilities in the accounting graduate (Stanley \& Marsden, 2012; Kavanah \& Drennan, 2008) and the use of case studies to support this (Hassel and Milne, 2004).

To ensure that both social and cognitive benefits of PBL are fully realised, considerable investment of the teacher's time is required at the front-end; the careful construction of relevant, stretching, real-world, and 'ill-structured' problems for students to solve, the provision of initial guidance about group work and the PBL process, and ongoing support, facilitation, and mediation for the groups (Peterson, 1997; Silén, 2006). Whilst many have catalogued the potential and success of PBL as a pedagogical approach, it is not without critique. Challenges cited in the literature include the lack of transferability to other 
disciplines beyond the more traditional practical-based disciplines (such as medicine and engineering) and the perennially thorny question of how the work is assessed (Azer, 2009; Lee, Lin, \& Lin, 2012; Boud \& Feletti, 1997; Barrett \& Moore, 2011).

Problem-based learning entails students working closely for a period in time in small groups and this introduces a number of issues to the accounting classroom. There is a plethora of literature about the potential of group work but also about the countless documented problems that students describe from their experiences of it (Hillyard, Gillespie, \& Littig, 2010). Several problems have been identified: firstly, doubts have been cast over group work's ability to increase students' cognitive development or motivation; and secondly, students consistently face and cite problems with group dynamics, with terms such as 'free-riding', 'coasting', and 'sucker effect' referring to the reduction of input from the more capable students when faced with students not deemed to be 'pulling their weight' (Davies, 2009; Kerr \& Bruun, 1983). Other questions include group selection (teacher or self-selected), optimum group size, the most effective ethnic and gender mix of groups, and how the teacher should recognise and reward group and individual effort (Seethamraju \& Borman, 2009; Cotton, George, \& Joyner, 2013). Dolmans, Wolfhagen, van der Vleuten, \& Wijnen, (2001) note the tendency for teacher-directed solutions to take precedence over student independence; they remind teachers of the constructivist nature of PBL learning and recommend teachers return to 'hold on to the underlying educational philosophy' of PBL and allow student-directed solutions to prevail (ibid: 884). Following a study of nursing students experiencing group work, Beccaria, Kek, Huijser, Rose, Kimmins (2014) argue that educators should do more to facilitate students' meta-cognition of the skills and attributes developed through the process and to think carefully about how they can best support struggling learners. Assessment is a particular issue that concerns both students and teaching staff, and more recommendations are made for assessing individual and group contributions, including careful weighting of both process and product, and peer assessment that can identify smaller contributions from certain students (Dijkstra, Latijnhouwers, Norbart, \& Tio, 2016).

Combining these divergent areas of literature, a significant gap in the literature has been identified - no specific examples of PBL being used to teach sustainability in Accounting Education were found following a combined keyword search ('sustainability' 'problem-based learning' and 'accounting'). Key words were searched in EBSCO Information Services, selecting databases of the British Education Index and Business Source Complete. This research project fills this gap by presenting a case study of the use of PBL in 
the accounting degree programme and students' perceptions of the value of this pedagogy in learning for sustainability.

\section{The study}

The module that forms the basis of this research is a third year elective accounting module that took place over two semesters with a cohort of 34 students. The module leader conceived the module as a result of her joint interest in both PBL and sustainability, and devised a supportive environment and module structure that together paid attention to the mechanisms by which effective group work skills could be developed. By the end of the module, learners were expected to be able to:

- Critically assess developments and rationales for sustainability accounting, drawing on knowledge of the theoretical foundations, current practice, regulatory environment and recent developments in accounting for sustainability

- Critically evaluate the effectiveness of different sustainable accounting models and techniques

- Synthesise and evaluate relevant, reliable research evidence and analyse academic research papers

- Demonstrate an ability to contribute effectively to class discussions, work effectively within a group and to present research arguments coherently

Assessment took the form of two formative group assessments (one presentation, one report) and two summative group assessments with $40 \%$ weighting (again, one presentation worth $20 \%$, one report worth $20 \%$ ), and one individual reflective essay that carried $60 \%$ weighting. The module leader created groups that assured a mix of gender, ethnicity, and ability, based on prior attainment. Over the course of the two semesters, after an introductory 'practice' scenario to demonstrate the process of PBL, students were given a series of four scenarios to work through around accounting for sustainability, sustainability reporting, socially responsible investment, and the relative merits of connected and integrated reporting. Scenarios were based on a different fictitious company each time to familiarise students with a wide range of contexts, and were accompanied by a selection of resources curated to stimulate deeper analysis, including videos, podcasts, text, references to books, reports, and articles, and stimulus images. Each scenario took the group three weeks to complete and culminated in a presentation or report, collectively produced and executed (see Table 1 for 
further details of the scenarios contained in the module handbook for students). (Table 1 near here)

Although the details are not within the scope of this paper, it is important to make reference to the steps taken to provide the optimal conditions for effective group work within the module. Following Bruner (1978), the elements of facilitation, support, and assessment structure that 'scaffolded' these conditions, with supporting evidence of impact from the student questionnaire, are outlined in Appendix 3 (see methodology below for further details).

\section{Methodology}

Education and its concomitant process, learning, are co-constructed and messy phenomena, with complex interactions in play amongst the three chief components of educational practice - namely, the learners, teachers, and curriculum. Ethnography has proved a valuable methodology for negotiating the messiness of compulsory education (Putney \& Frank, 2008; Holland, Gordon, \& Lahelma, 2007; Gustafson, 2009; Robinson, 2008), although it has featured considerably less in higher education research (Pabain, 2014; Cousin, 2009). The 'methodological orientation' of ethnography enables the researcher to experience the context and people under study at first hand, and not become reliant solely on spoken accounts of experience in focus groups or interviews (Hammersley, 2006:4).

The rationale behind choosing an ethnographic approach in this study was to facilitate access to the students' lived experiences of the module in situ across a full year and then to interrogate their subsequent perceptions of the value of PBL and sustainability in their accounting degree, and the meanings they had constructed, through semi-structured interviews towards the end of the module. Throughout the research period, this 'foreshadowed problem' of perception of value was kept in mind (Malinowski, in Cousin, 2009:114), with observations and interviews refracted through this lens. Thirty-four students registered on the final-year module but limited resources ensured that only the experiences of a small number of these could be explored; at the start of the module, once the groups had been established, a group was asked to volunteer to be part of the study. One group volunteered, consisting of four males and two females, four being white British, one AsianBritish ethnicity, and one international Chinese student.

The methods entailed ethnographic observations of this self-selected group of six students over two semesters (between October and May). Recent ethnographic research has 
shifted away from the traditional style of intense, long periods of participant observation, particularly in education where the 'field' under study is often close to home or sessional work encouraging shorter bursts of observations. In this study, the researcher undertook observations of introductory lectures and information sessions, and of the group working together during the course of the year to address the four 'problem' scenarios, both within scheduled times and separate study sessions arranged by the group (around 50\% of the programme was observed). The two presentations that formed two assessment points were also observed.

These observations generated field notes, the analysis of which yielded over-arching themes and recurrent issues that emerged from the students' comments and behaviour (emic themes such as learning spaces, tackling the PBL seven-step process, and participant styles of interaction with the group), which in turn formed the basis of the semi-structured interviews (see Appendix 1 for interview questions). Conversational-style interviews were conducted with each of the six student group members, where the researcher shared her observations and invited the students to give their own accounts of what they experienced in the module and within the group. The question was also raised in each interview of whether the researcher's presence as an observer had affected the group behaviour; all students interviewed claimed that it had not and that they had forgotten she was there much of the time. As someone not directly connected to the assessment of the module, it was hoped that the researcher would maintain enough distance for the students to feel they were able to speak frankly about their experiences of the module. The coding system utilised in this paper is depicted in Table 2. (Table 2 near here)

Finally, addressing the need to understand different groups' experiences of the PBL process, a survey of the entire cohort of students was designed by the module leader and conducted at the end of the module. Non response bias was mitigated through the use of an anonymised, well-designed survey and the request for students to complete in class, and as a result the survey received a $65 \%$ return rate (22 out of a possible 34 ). The survey contained 36 questions, using a variety of Likert scale responses and open questions around the two core components of the module, group work and sustainability (see Appendix 2 for survey questions). Details were elicited around the process of PBL (e.g. value of seven steps, development of problem-solving skills, optimum group size, etc.) and what students felt they had learnt about sustainability. The sample size was too low to perform statistically 
significant analytical tests, but descriptive statistics are included in the results. Quotations from the survey are identified by $(\mathrm{Q} 2, \mathrm{Q} 15$, etc.)

The periods of time spent with this group totalled on average two hours a week for around six months, which resulted in observations that were both periodic and ahistorical. Educational ethnographers have highlighted the question of how valid and generalisable such research can be in other contexts (Hammersley, 2006); thus, with a close focus on the microcontext of one module, the literature review and discussions in this paper directly address this issue by contextualising these findings in the broader arena of student learning in accounting education.

\section{Results and discussion}

The research project generated a considerable body of data in the form of observational field notes, interview transcripts, and survey results. The qualitative data was analysed using a 'sense-making' approach where 'analysis refers primarily to the imaginative work of interpretation, and the more procedural, categorizing tasks are relegated to the preliminary work of ordering and sorting the data' (Coffey \& Atkinson, 1996, 6).

Observations informed the development of interview questions, the transcripts of which were analysed and used to construct a narrative of the module and how it was experienced by students. This was triangulated with perspectives from the accounting education and educational development fields on the importance of sustainability and PBL pedagogies. Two key research questions are considered in turn below.

\subsection{What are students' perspectives on the importance of learning about sustainability in} their undergraduate Accounting degree programme?

The students found their study of sustainability to be of value to them in their accounting programme; it added depth to their accumulated traditional and skill-based accounting knowledge acquired over the previous two years of study, and was perceived as directly relevant and topical to the accounting and associated professions that many of them were planning to enter (just over half of accounting graduates on this programme secured a professional job in the field (DLHE, 2015-16)). Although it might be assumed students selected the elective module due to a predisposed interest in sustainability, it became apparent that motivations to take the module varied: one student remarked they had chosen the module out of a personal interest in sustainability, to discover how it could be related back to their accounting knowledge already acquired during the programme: 
[...] it's nice to see how both the topics [general accounting and sustainability modules] that I do enjoy do entwine. So it has definitely been enjoyable. And I would do it again, definitely. (FS, survey)

Another student recognised that taking the module was a way of acquiring what they considered a topical specialism or 'niche' in accounting:

Furthermore, sustainability has become more and more apparent during my first two years of the course, as not a mere 'trend' but a permanent concept that businesses are implementing for the long-term. Therefore I saw the module as an opportunity to begin specialising in a niche area of accounting, away from the standard modules. (WB, survey)

For others, the module enabled them to explore an area of accounting that simply interested them in more depth. This choice element inevitably increased the students' motivation to learn about the role of sustainability within the accounting profession and their engagement in the module activities. The 'problems' or scenarios of real issues in accounting were wellreceived and provided good motivation to complete the tasks successfully:

When I was handed this scenario I was pleased as investment portfolios interest me, so this new twist of ethical and green investments made me keen to thoroughly research it. (EM, survey)

Several students adopted the normative perspective that understanding different ways of doing accounting was essential for moving the profession forward, as highlighted in the literature from proponents of significant change in accounting education towards more environmentally-responsible processes. One Chinese student wrote:

[...] I know the pollution in China is becoming more serious than ever before despite the general public is paying more attention to this issue. Therefore, I was thinking how could I contribute to make the change in the knowledge that I have gained from the A-level and university in the aspect of environmental protection. I know all types of companies are an essential factor in our society and play a vital critical role in our daily life. Thus, if companies are caring more about environmental issues the situation would become better and this is my initial reason to choose this module. (ZT, survey)

A strong sense of value for students learning about sustainability emerged in the form of its bearing on their employability, indicating a welcome and significant shift since Collison, et 
al's (2000) survey of students. In the Collison survey, students responded that they would not choose an Environmental Auditing elective as they did not perceive it to be of benefit to their future job prospects. In the sustainability module in this study, students conveyed their perceptions of the benefit of sustainability knowledge and skills in accounting to their future work prospects in the region:

I think learning it now we're probably a few steps ahead of a lot of people in their business; when I get to work, I think a lot of people have no idea really. (S6)

[...] I believe that with sustainability becoming a key issue across all companies I will be able to use this knowledge as a competitive advantage in the future in my graduate job. (EM, survey)

[I]t's definitely got me thinking, you know, wherever I do work, this could be something that they might even be doing now or considering doing. (S4)

This could firstly give me the edge in the graduate job market, and secondly give me the edge in practice, having an understanding of key sustainability issues as they become more pressing mandatorily as well as voluntarily. (WB, survey)

Two students recounted their perception that learning about sustainability had given them a distinct advantage over other students who had had no exposure to sustainability in securing a graduate position:

My new understanding of sustainability puts me in the smaller percentage of the population and increases my employability immensely. Using the knowledge gained from the module assisted me in my interviews and helped me secure a graduate position. It seems the world is going in the direction where knowledge on sustainability is not only beneficial but also almost expected for upcoming young professionals. (MO, survey)

I talked about it in my interview for a grad job and they really liked it. [...] I was talking about sustainability and how it affects the business and stuff, and then I was talking about not only the environmental facts but also about the social facts as well. I was saying how I liked that the company does all these extra things for sustainability, and they seemed to really like it. And when they called me, they said they liked my view on sustainability and stuff. (S1) 
The value of studying sustainability within their accounting programmes was consistently clear to the students in the research. However, the perennial issue of the contestability and ambiguity of sustainability was raised in the module; the lack of a definitive way to do accounting for sustainability was troubling to many of the students, and they concurred that the module had been good at introducing sustainability but less effective at introducing clear methods or accounting tools. The emerging nature of sustainability accounting practices was highlighted to students in the module, but this wariness of less 'tried-and-tested' methods and knowledge can also be located in the literature, where there are different views on how education for sustainability in accounting should be tackled. Gray (2013) proposes that students should be provoked, challenged, and disoriented in order to place them in a position to rethink their beliefs and assumptions about the world and the role of accounting within it. However, in his response to Gray's paper, Contrafatto (2013) suggests that students can learn productively without the need for demoralisation and despondency. The approach in this module was more pro-active and hopeful; by presenting problems, and requiring students to solve them together, this appeared to generate enthusiasm and hope, and brought about the transformation of opinions and development of skills. Indeed, it was the focus on the praxis of working towards sustainability - learning to collaborate, solving problems together, and resolving differences - that formed the cornerstone of this module. The element of hope and potential for transformation is pivotal; as Contrafatto says, 'If we are to stay awake at night we should dream of better futures as well as our nightmares.' (2013: 339). Learning about, and for, sustainability requires a pedagogical approach that can deal with this 'mess' - problem-based learning (PBL) provided a suitable pedagogy in this module.

\subsection{How valuable do students perceive problem-based learning (PBL) to be as a vehicle for} learning about sustainability?

This second research question sought to explore the value of PBL as a pedagogical approach within accounting. Results from the survey of the whole cohort of students were conclusive that PBL was a valuable pedagogical approach for learning about sustainability; just three students (14\%) in the survey felt that they would have learnt more through a conventional lecture/tutorial delivery whilst 11 students $(50 \%)$ believed that they learnt more using PBL. The remaining students indicated no preference, although in the final survey question (Q36 in Appendix 1) that asked how they would prefer to be taught in the future, one student indicated they would prefer to be taught solely by PBL and the remaining 
students said they would like a blend of PBL with more traditional lectures and guest speakers.

Firstly, students believed that the module enabled them to build significantly on their prior, and incomplete, knowledge of sustainability. Nearly half of the 23 students who responded (48\%) agreed that they already possessed some understanding of 'sustainability' at the start of the module but 20 students agreed (43\% of which strongly agreed) that their understanding of sustainability had changed by the end of the module. Some $80 \%$ of students agreed that some of the material presented or researched during the module had challenged their views of the role of accounting and sustainability. One student expanded their response:

This module has facilitated massive development from my basic and biased starting point to understanding the breadth of the field. My interest has been further stimulated in the climate change argument, studying the carbon reporting rationales and methods. Not only prior held interests have been furthered, but new interests roused across sustainability particularly how to invest sustainably and the effects that could have. I will carry my developed beliefs into practice. (WB, survey)

The students also reported that they had become familiar with the wider notion of sustainability, beyond the confines of environmental concerns, as this student remarked in interview:

I definitely feel like I've learnt a lot more regarding the different aspects of sustainability, but not just the three pillars but issues affecting accounting, the future, different ways of reporting, that kind of thing. And I think when you do your own research, you're not doing it just for the scenarios, but you're actually doing it for yourself because this, you know, this could affect you in the future. (S4)

Specifically, the module encouraged them to change their perceptions on what sustainability is, sometimes quite radically. The researcher observed one student (WB) walking into the classroom on the first session claiming he did not believe in climate change, but went on to have profound shifts in his attitude towards sustainability. Others' understanding of what sustainability meant in terms of business and accounting shifted through discussion and research with others, in line with the social constructivist aims of PBL:

Before starting the course [...] I still believed though that generally most companies were solely driven by profits and these steps were just driven by saving costs. 
Throughout the course I came to realise that there is a lot more to sustainability and completely changed how I see the concept. (MR)

The interviews revealed that the students held expectations about the 'knowledge' of sustainability they would gain through participation in the module and their beliefs that they would learn about various sustainability-specific auditing tools. Twenty students (86\%) agreed that the PBL scenarios had stimulated their learning about sustainability but two students believed the use of real-life scenarios, perhaps from local businesses with sustainability issues, would have been more useful and interesting. The content of the scenarios focused on the exploratory side of sustainability auditing, rather than delivering fixed and certain tools for future use. Ninety-one per cent (21 students) agreed that the scenarios were authentic and sufficiently complex to require a group to complete them, and 14 students $(64 \%)$ believed that being exposed to engaging tasks was an important factor in their learning.

Problem-based learning entails students producing collaborative solutions to the scenarios based on their own research into the subject matters raised. Being exposed to a range of research into sustainability meant the students discovered through the course of the module that sustainability knowledge(s) is ambiguous. As described before, this left the students confused and less certain about the tools they would need for accounting for sustainability. The interviews yielded rich conversations about the nature of the contested knowledge of sustainability and several of the students shared their unease with this. One student spoke of his desire for 'the full picture' (S2). Despite this uncertainty, the students also recognised that sustainability accountancy was in its infancy with attendant tools that were inevitably less evolved than more traditional techniques. They had some sense that the nature of knowledge around sustainability was uncertain and contested, offering no clear path forward, and that they were called upon to work within these fluid parameters:

[I] t's all a bit wishy-washy at the moment, but I think it is going to become the standard and the norm. (S6)

I think it's quite weird because sustainability itself is such a new kind of issue, and there's no real right answer right now. [...] there's research done, but there's no right way, proper outlet at the moment. (S2)

One student expressed the cynical aspect of 'trends' in accountancy: 
[I]t's a buzzword for companies nowadays, sustainability, and I think any candidate that goes in and mentions it will get them Brownie points. (S1)

Another student's sense of identity as a professional was challenged:

But [sustainability is] very wide and different people see - there's so many different definitions, which I think is what makes this subject very interesting, but also quite frustrating, because, being an accountant, you want to get to - personally, I like a right or a wrong. (S6)

Yet another student expressed his anxiety about acquiring the 'right' knowledge and his uncertainty that his research was bringing up core knowledge or marginal information:

[W]ith me, I felt that what I was learning, was it correct? That was my only worry that I had on the PBL scenarios was obviously when it's traditional, you get told what you need to know. (S4)

The reflective component of the final assessment afforded this student, and others, the potential to reflect on their relationship with fundamental aspects of the discipline of accountancy; epistemological questions over the nature of knowledge and information as well as ontological questions of the purpose and direction of their anticipated profession. Being exposed during the module to a 'broader picture' of accountancy was important:

[A]s an accountant, working in finance, you're obviously worried about the bottom line, so I guess it's quite good to, actually, there's more to it than just numbers. But how do you measure something that isn't a number? So the social aspect, how would you measure that? [...] So I guess it is useful, because you think about it, the sustainability aspect and the broader picture. (S2)

The second area in which PBL proved to be valuable for learning about sustainability relates to the skills the students developed throughout their engagement in the module. Three clear areas of skill development emerged from the interview analysis: group work or collaboration, dealing with conflict and group dynamics, and leadership. It is common to hear from undergraduate students that group work is often perceived and experienced to be an undesirable facet of their higher education experience, to be avoided if at all possible. The PBL process actively promotes group work as the optimal means to solve intractable and 
troublesome problems. Working with different others in a small research team lent the students a useful perspective on team work and collaborative working:

I have not only gained knowledge in this module but through the PBL process I have learnt how to manage and work with different types of people, something which will be transferable into not only the workplace but also in daily life. (EM, survey)

This module [...] gave me a team-working experience that I have never had before. I learnt how to work with others, how to help others and how to work in a group with different background. In the future, I believe people work in the same place will have different background. Such as culture, language and religion. I am glad that I had this experience before get a job and I believe this will certainly benefit me in the future. (ZT, survey)

Difference in groups inevitably results in different approaches, abilities, and values in working, and can lead to tension, disharmony, suboptimum productivity, and sometimes outright conflict. Nine students (39\%) revealed they had experienced some degree of conflict in their PBL groups; despite the majority of these respondents saying they had not been able to satisfactorily resolve the differences encountered, the conflict they experienced, although unpleasant and challenging at the time, raised their awareness of the need to develop new skills in promoting productive groups. One student commented:

I believe the teamwork skills I learnt though this PBL process will aid me in my future. I now know how to approach group members who are in conflict and keep the rest of the group calm when there is a problem. (MO, survey)

The PBL process also afforded certain students the opportunity to lead the group and enhance their leadership potential. This student demonstrates the wealth of skills the leadership opportunity offered him:

The group also developed my leadership skills, being the first time I had led a group for such a long period of time allowing refinement of our own methods and numerous stages of formation to occur. The skills this demanded included diplomacy, having to put personal interest or frustration aside for the benefit of the team, as well as people management to identify strengths and weaknesses to ensure the group works efficiently and harmoniously. (WB, survey) 
In general, the perceived value of PBL to the students was unequivocal. Observations of each session revealed higher attendance than for any other module encountered in the researcher's role of academic development and practice review, and a palpable degree of engagement hitherto not encountered amongst undergraduates in more traditional teaching contexts. The value of PBL in developing employability attributes has been covered in the previous section. There were also demonstrable inter-cultural benefits as groups were mixed with home and international students, a factor of not inconsiderable value in a predominantly homogenous geographical region:

I have made new friends, including friends from a culture to which I have had minimal exposure both pre and during University. The ability to meet a new group and instantly learn, evaluate and adapt to a different culture you come into contact with will be crucial moving into the professional world where diversity is blooming. $(W B)$

The collective elaboration of a social constructivist approach was an important element for some. Reflecting on the pedagogical aspect of PBL, two students clearly recognised a positive difference between this module and others in their Accounting programme:

I thought it was a better way of teaching, to be honest, rather than lectures for that subject and it would be applicable for every subject. I just thought it was a good way to teach because, instead of having boring lectures, like someone talks to you for however long, you can work out yourselves with a group. That way, you actually see six peoples' research rather than just what the lecturer's researched, what they can give you in an hour. (S6)

And I have recommended it for people that I know in the year below, in case they wanted to do something different, something to actually get you thinking rather than just 'I need to learn this, go over it and then just basically listen to a lecture'. (S4)

Although one student noted that this form of student-centred learning comes at a price, it was perceived to be 'worth it': 
This module has been time-consuming throughout the year, a negative vastly outweighed by the knowledge, experience, interests and skills I have left with; a highly enjoyable and recommendable module. (WB, survey)

Overall, the feedback from the interviews and surveys revealed that most students had liked the module and could appreciate the value of the PBL process for getting them to learn independently:
At first I was hesitant about problem-based learning. It wasn't the fact that I'd have to go and do pretty much everything myself, it was more the fact that I was put into a group that, even though I knew a few members, I didn't know other people. And if I was getting graded on that, it was a 'do I trust' kind of thing. And I think my final year was a bit nerve wracking because obviously you want to do your best. But no, I thoroughly have enjoyed PBL. (S4)

The conclusion to this research question is that PBL is perceived by students on this module to have been valuable for developing skills for sustainability, such as collaborative working, conflict resolution, and leadership, as well as learning about sustainability.

\section{Limitations of study}

As a small ethnographic case study (Thomas, 2013) that serves to illustrate and analyse the role of PBL in learning for sustainability, this research project had a number of evident limitations. The small sample size of six students for in-depth interviews and observations, and a larger survey of 23 students, could be perceived to limit the validity and generalisation of the findings. This limitation was mitigated to some extent by the authors' choice of methodology and belief in the fundamental ethnographic principle that affords extrapolation of the singular experience to the multiple and far-reaching (Marcus, 1995). As such, this research confidently claims to offer a snapshot of learning in the accounting classroom in a sustainability module, which possesses clear implications for practice elsewhere. The researcher's presence in the classroom had the potential to influence student behaviours, but no such influence was reported by members of the observed group when asked directly. A further limitation was revealed as the module progressed - the group who volunteered to be part of the research turned out to be the most able group, highlighting the absence of the voices of the less-able students in this study. Again, this was mitigated to some degree by conducting the survey, which managed to capture a number of those missing 
voices, albeit on a more superficial level. Finally, had data from students' reflective essays been included, a deeper picture of the role of sustainability in their learning might have resulted.

\section{Conclusions}

The evidence presented in this small ethnographic study points to the far-reaching value of including a sustainability module in accounting programmes, and to the distinct advantages of using a problem-based learning approach. Findings reveal that students perceived the value of the module to lie in its aim to introduce them to a broader and more nuanced understanding of sustainability and to highlight the existence of emerging alternatives to traditional accounting processes. Indeed, the contingency, complexity, and constructed nature of sustainability knowledge(s) lends itself well to this form of problembased pedagogical approach. Specifically, through adopting a problem-solving approach, the module facilitated the critique of existing practices by presenting students with the opportunity to encounter and appraise new forms of reporting encountered in the scenarios. The research also found evidence that students recognised their development of employability-related skills in problem-solving, collaborative working, conflict resolution, report writing, presentations, and research; these were more visible to the students than the development of specific accounting-related skills. However, the simple exposure of students to the new topic (for many) of sustainability was perceived as more important than skill acquisition in enhancing their employability.

Secondly, this paper concludes that students perceived PBL to be a valuable and apposite pedagogy for learning about sustainability in the accounting curriculum. It encouraged students to revisit their prior knowledge of sustainability and, in some cases, led to the transformation of their viewpoints. Importantly, problem-based learning requires a supportive approach to group work to gain maximal benefit from the pedagogical approach. Indeed, it is important to state that only by designing the group work well and preparing students for the problem-solving process can problem-based learning be fully effective at engaging students and go some way towards developing another key competence for sustainability - the ability to work collaboratively and resolve differences (Barth, Godemann, Rieckmann, \& Stoltenberg, 2007; Wiek, Withycombe, \& Redman, 2011). Careful scaffolding is required for group formation and working, and peer assessment processes, and this has been outlined in this paper. As Davies (2009) and Dijkstra, et al, (2016) recommend, student learning is enhanced by providing the best possible opportunity for successful group 
work, and it is incumbent on academic staff to understand the mechanics of effective group work and to create supportive environments and resources for its cultivation.

It is recognised that for other institutions considering changes to their accounting programmes, there are two implications for adopting sustainability as a core module. Firstly, when the elements of choice and self-selection have been removed from the programme, it is possible that staff might witness a decline in student motivation and interest in sustainability. Whilst it is appreciated that it is rewarding to run a module where student engagement is high, as was the case in this study, the authors contend that the time has passed for sustainability to be viewed as a 'luxury' curricular item and that there are ways to maintain engagement through scenario development and pedagogical approaches. Secondly, since this study was conducted, the authors' university has moved to a single semester system like many universities around the world, with implications for the number of problem-solving scenarios the module could cover in twelve weeks. It is possible that the depth and breadth of learning in a single semester through PBL could be compromised with groups having less time to develop their skills over time, although it is highly feasible that assessment could still be as effective when reduced to just one formative and one summative assessment. One mitigation might be through the introduction of PBL to other accounting modules, such that the development of students' acumen in the problem-solving process is spread across more than one module and level. With these limitations in mind, and with the necessary amendments in place, the authors argue that sustainability should constitute a core module in all accounting programmes in the interests of students, the accounting profession, and society at large. It is appreciated that the accounting education field is some distance from this advanced stage of 'embeddedness' (Wyness, Jones, \& Klapper. 2015) but it is surely time for sustainability to progress from being a 'welcome guest' in accounting (Gray, 2013) to becoming a permanent subject-in-residence.

\section{Acknowledgements}

The authors wish to thank the two anonymous reviewers for their detailed and valuable comments, and Editor-in-Chief Natalie T. Churyk for her excellent guidance throughout the process. They also wish to thank the accounting students who were involved in this research and shared their views and perspectives, and to their colleagues for useful feedback in the drafting of this paper. 


\section{References}

Apostolou, B., Dorminey, J.W., Hassell, J.M. \& Rebele, J.E. (2017). Analysis of trends in the accounting education literature (1997-2016). Journal of Accounting Education, 41, 1-14. Azer, S.A. (2009). Challenges facing PBL tutors: 12 tips for successful group facilitation. Medical Teacher, 27(8), 676-681.

Barrett, T. \& Moore, S. (2011). (eds) New approaches to problem-based learning: Revitalising your practice in higher education. New York \& London: Routledge.

Barrows, H. (1986). A taxonomy of problem-based learning methods. Medical Education, 20, 481-486.

Barth, M., Godemann, J., Rieckmann, M. \& Stoltenberg, U. (2007). Developing key competencies for sustainable development in higher education. International Journal of Sustainability in Higher Education, 8(4), 416-430.

Bebbington, J. (1997). Engagement, education and sustainability. Accounting, Auditing \& Accountability Journal, 10(3), 365-381.

Bebbington, J. \& Thomson, I. (2005). Social and environmental reporting in the UK: a pedagogic evaluation. Critical Perspectives on Accounting, 16(5), 507-533.

Beccaria, L.M., Kek, M., Huijser, H., Rose, J., Kimmins, L. (2014) The Interrelationships Between Student Approaches To Learning and Group Work. Nurse Education Today, 34(7), 1094-103.

Bloom, B., Engelhart, M., Furst, E., Hill, W., \& Krathwohl, D. (1956). Taxonomy of educational objectives: The classification of educational goals. Handbook I: Cognitive domain. New York: David McKay Company.

Botes, V., Low, M. \& Chapman, J. (2014). Is accounting education sufficiently sustainable? Sustainability Accounting, Management and Policy Journal, 5(1), 95-124.

Boud, D. \& Feletti, G. (1997). (Eds.). The challenge of problem-based learning. London: Kogan Page.

Breton, G. (1999). Some empirical evidence on the superiority of the problem-based learning (PBL) method. Accounting Education, 8(1), 1-12.

Brundiers, K. \& Wiek, A. (2013). Do We Teach What We Preach? An International Comparison of Problem- and Project-Based Learning Courses in Sustainability.

Sustainability, 5, 1725-1746.

Bruner, J.S. (1960). The process of education. Cambridge, Mass: Harvard.

Bruner, J. S. (1978). The role of dialogue in language acquisition. In A. Sinclair, R., J. Jarvelle, and W. J.M. Levelt (Eds.) The Child's Concept of Language. New York: SpringerVerlag.

Coffey, A. \& Atkinson, P. (1996). Making sense of qualitative data. Complementary research strategies. London: Sage.

Collison, D., Gray, R., Owen, D., Sinclair, D., \& Stevenson, L. (2000). Social and environmental accounting and student choice: an exploratory research note. Accounting Forum, 24(2), 170-186.

Contrafatto, M. (2013). 'Utopia' and 'Passion': A Commentary on 'Sustainability and Accounting Education: The Elephant in the Classroom'. Accounting Education, 22(4), 336339.

Cotton, D.R.E., George, R. \& Joyner, M. (2013). Interaction and influence in culturally mixed groups. Innovations in Education and Teaching International, 50(3), 272-283. Coulson, A. \& Thompson, I. (2006). Accounting and Sustainability, Encouraging a Dialogical Approach; Integrating Learning Activities, Delivery Mechanisms and Assessment Strategies. Accounting Education. 15(3), 261-273. 
Cousin, G. (2009). Researching Learning in Higher Education: An Introduction to

Contemporary methods and Approaches. New York and Oxon, UK: Routledge.

Davies, W.M. (2009). Groupwork as a form of assessment: common problems

and recommended solutions. Higher Education, 58, 563-584.

Dawe, G., Jucker, R. \& Martin, S. (2005). Embedding ESD into HE: Final Report for the

Higher Education Academy. York: Higher Education Academy.

Day, M.M. (1995). Ethics of teaching critical: feminism on the wings of desire. Accounting,

Auditing \& Accountability Journal, 8(3), 97-112.

Dean, B.A., Perkiss, S., Misic, M.s. \& Luzia, K. (2018). Transforming accounting curricula

to enhance integrative learning. Accounting and Finance. DOI:

https://doi.org/10.1111/acfi.12363

DLHE (2015-16) Destination of Leavers in Higher Education, Office for Students (formerly HEFCE). London: UK Government.

Dijkstra, J., Latijnhouwers, M., Norbart, A. \& Tio, R.A. (2016). Assessing the "I" in group work assessment: State of the art and recommendations for practice. Medical Teacher, 38(7), 675-682.

Dobson, H.E. \& Tomkinson, C.B. (2012). Creating sustainable development change agents through problem-based learning: Designing appropriate student PBL projects. International Journal of Sustainability in Higher Education, 13(3), 263-278.

Dochy, F., Segers, M., Bossche, P. \& Gijbels, D. (2003). Effects of problem-based learning: a meta-analysis. Learning and Instruction, 13, 533-568.

Dolmans, D.H.J.M., Wolfhagen, I.H.A.P., van der Vleuten, C.P.M. \& Wijnen, W.H.F. (2001). Solving problems with group work in problem-based learning: hold on to the philosophy. Medical Education, 35, 884-889.

Dyball, M.C. \& Thomson, I. (2013). Sustainability and Accounting Education. Accounting Education, 22(4), 303-307.

Gam, H.J. \& Banning, J. (2011). Addressing Sustainable Apparel Design Challenges with Problem-Based Learning. Clothing and Textiles Research Journal, 29(3), 202-215.

Gewurtz, R., Coman, L. Dhillon, S. Jung, B. \& Solomon, P. (2016). Problem-based Learning and Theories of Teaching and Learning in Health Professional Education. Journal of Perspectives in Applied Academic Practice, 4(1), 59-70.

Gijselaers, W (1995). Perspectives on problem-based learning. In

Gijselaers, W., Tempelaar, D., Keizer, P., Blommaert, J., Bernard, E. \& Kapser, H. (Eds.), Educational Innovation in Economics and Business Administration: The Case of ProblemBased Learning (pp 39-52). Dordrecht: Kluwer.

Gray, R. (2013). Sustainability and Accounting Education: The Elephant in the Classroom. Accounting Education, 22(4), 308-332.

Gray, R. \& Collison, D. (2002). Can't see the wood for the trees, can't see the trees for the numbers? Accounting education, sustainability and the public interest. Critical Perspectives on Accounting, 13, 797-836.

Gustafson, K. (2009). Us and them - children's identity work and social geography in a Swedish school yard. Ethnography \& Education, 4(1), 1-16.

HEFCE (2005). Sustainable Development in Higher Education - Statement of Policy. Bristol: Higher Education Funding Council for England.

Hammersley, M. (2006). Ethnography: problems and prospects. Ethnography and Education, 1(1), 3-14.

Hassall, T. \& Milne, M.J. (2004). Using case studies in accounting education. Accounting Education, 13(2), 135-138.

Hansen, J.D. (2006). Using Problem-Based Learning in Accounting. Journal of Education For Business, 81(4), 221-224. 
Hazelton, J. \& Haigh, M. (2010). Incorporating Sustainability into Accounting Curricula: Lessons Learnt From an Action Research Study. Accounting Education, 19(1-2), 159-178. Hillyard, C., Gillespie, D., \& Littig, P. (2010). University students' attitudes about learning in small groups after frequent participation. Active Learning in Higher Education, 11(1), 9-20. Holland, J., Gordon, T., \& Lahelma, E. (2007). Temporal, spatial and embodied relations in the teacher's day at school. Ethnography \& Education, 2(2), 221-237.

Hopwood, A., Unerman, J. \& Fries, J. (2010). Accounting for Sustainability: Practical Insights. Oxon \& New York: Routledge.

Johnstone, K. M., \& Biggs, S. F. (1998). Problem-based learning: introduction, analysis, and accounting curricula implications. Journal of Accounting Education, 16(3), 407-427.

Jones, P., Selby, D. \& Sterling, S. (2010). Sustainability Education: Perspectives and Practice across Higher Education. London and Washington, DC.: Earthscan.

Kavanah, M.H. \& Drennan, L. (2008). What skills and attributes does an accounting graduate need? Evidence from student perceptions and employer expectations. Accounting \& Finance, 48(2), 279-300.

Kelly, M. \& Alam, M. (2009). Educating Accounting Students in the Age of Sustainability. The Australasian Accounting Business \& Finance Journal, 3(4), 30-44.

Kerr, N., \& Bruun, S.E. (1983). Dispensability of member effort and group motivation losses: Free-rider effects. Journal of Personality and Social Psychology, 44, 78-94.

Lee, G-H. Lin, C-S. \& Lin, Y-H. (2012). How experienced tutors facilitate tutorial dynamics in PBL groups, Medical Teacher, 35(2), e935-e942.

Lee, W.E., Birkey, R.N., \& Patten, D.M. (2016). Exposing students to environmental sustainability in accounting: an analysis of its impact in a US setting. Social and Environmental Accountability Journal, 37(2), 81-96.

Lehmann, M., Christensen, P., Du, X. \& Thrane, M. (2008). Problem-oriented and projectbased learning (POPBL) as an innovative learning strategy for sustainable development in engineering education. European Journal of Engineering Education, 33(3), 281-293.

McPhail, K. \& Gray, R. (1996). Not developing ethical maturity in accounting education: hegemony, dissonance and homogeneity in accounting students' world views. Discussion Papers in Accountancy and Business Finance ACC/9605, University of Dundee.

Marcus, G.E. (1995). Ethnography in/of the World System: The Emergence of Multi-Sited Ethnography. Annual Review of Anthropology, 24, 95-117.

Natoli, R., Jackling, B. \& Seelanatha, L. (2014). The impact of instructor's group management strategies on students' attitudes to group work and generic skill development. Pedagogies: An International Journal, 9(2), 116-132.

Owen, D., Humphrey, C., \& Lewis, L. (1994). Social and environmental accounting education in British universities. London: Chartered Association of Certified Accountants. Pabain, P. (2014). Ethnographies of higher education: introduction to the special issue. European Journal of Higher Education, 4(1), 6-17.

Peterson, M. (1997). Skills to Enhance Problem-based Learning. Medical Education Online, 2(1), 4289.

Piaget, J. (1971). Psychology and Epistemology: Towards a Theory of Knowledge. New York: Grossman.

Putney, L.G., \& Frank, C.R. (2008). Looking through ethnographic eyes at classrooms acting as cultures. Ethnography and Education, 3(2), 211-228

Robinson, S. (2008). Trusting the method: an ethnographic search for policy in practice in an Australian primary school. Ethnography \& Education, 3(3), 243-252.

Ryan, A. \& Cotton, D. (2013) Times of Change: Shifting Pedagogy and Curricula for Future Sustainability. In Sterling, S., Maxey, L. \& Luna, H. (Eds.). The Sustainable University Process and Prospects (pp. 151-167). Abingdon: Routledge. 
Ryan, A. \& Tilbury, D. (2013). Uncharted waters: voyages for Education for Sustainable Development in the higher education curriculum. The Curriculum Journal, 14(2), 272-294. Seethamraju, R. \& Borman, M. (2009). Influence of group formation choices on academic performance. Assessment \& Evaluation in Higher Education, 34, 31-40.

Sharma, U. \& Kelly, M. (2014). Students' perceptions of education for sustainable development in the accounting and business curriculum at a business school in New Zealand. Meditari Accountancy Research, 22(2), 130-148.

Silén, C. (2006). The tutor's approach in base groups (PBL). Higher Education, 51, 373-85. Stanley, T. \& Marsden, S. (2012). Problem-based learning: Does accounting education need it? Journal of Accounting Education, 30(3/4), 267-289.

Thomas, I. (2008). Critical Thinking, Transformative Learning, Sustainable Education, and Problem-Based Learning in Universities. Journal of Transformative Education, 7(3), 245264.

Thomas, G. (2013). From question to inquiry: operationalising the case study for research in teaching. Journal of Education for Teaching, 39(5), 590-601.

Thomson, I. \& Bebbington, J. (2002). Social and Environmental Reporting in the UK: A Pedagogic Evaluation. Aberdeen Papers in Accountancy, Finance \& Management. Working Paper 02-01. ISSN 0962-4627.

Unerman J, Bebbington J, \& O’Dwyer, B. (2007). Sustainability, Accounting and Accountability. Oxon \& New York: Routledge.

Vygotsky, L. (1978). Interaction between learning and development. In Gauvain \& Cole (Eds) Readings on the development of Children (pp. 34-40). New York: Scientific American Books.

Wiek, A., Withycombe, L., \& Redman, C. L. (2011). Key competencies in sustainability: A reference framework for academic program development. Sustainability Science, 6, 203-218. Wyness, L., Jones, P. \& Klapper, R. (2015). Sustainability: what the entrepreneurship educators think. Education + Training, 57(8/9), $834-852$. 


\section{Appendices}

\section{Appendix 1}

Interview questions

\section{Group dynamics}

1. How did you appoint a leader? How did that work?

2. Do you think the group behaved any differently by being observed?

3. How did you find working in this group? What have you learnt? About group work, about yourself?

4. What challenges did you face personally?

5. How do you think the quieter/talkative students felt about group work?

6. How did you feel the group developed over the four scenarios? Did you recognise the forming/norming/storming sequence?

7. Have your opinions about group work changed since doing this module?

8. How do you feel it related to the world outside the classroom?

\section{PBL process}

1. How does it feel to start a task? Talk me through what you do.

2. How useful/usable did you find Moodle?

3. How have you shared documents/progress? How was the report compiled? Roles assigned?

4. How did you find/are you finding the reflective writing assignment? What are your feelings about reflection? Can you see the purpose/value in it?

5. Which output did you prefer - presentation or report? What were the challenges of each?

6. Editing process - was this the best way to edit it in retrospect? Did you assume you have to edit together? Or were you told to?

7. How did the physical space of the room help/hinder your collaboration?

8. How do you see the role of the facilitator? Has she offered you sufficient and timely support?

9. How do you feel PBL compares to traditional lectures/exams?

\section{Sustainability}

1. What did you learn about sustainability? Is this a good way to learn about sustainability? 


\section{Appendix 2}

\section{PROBLEM BASED LEARNING AND SUSTAINABILITY QUESTIONNAIRE}

This survey forms part of a research project which aims to evaluate problem based learning (PBL). All information provided as part of this research will be treated as confidential, and will have no impact on your University education. You do not have to take part in the research, and you may choose to withdraw at any stage, but it would help us greatly if you could try and answer all the questions as fully as you can-feel free to add extra comments if you wish.

Please note that there are no 'right' or 'wrong' answers as all information supplied is perfectly valid! Thank you

This questionnaire is intended to be anonymous but the following information, from questions 1-3, will allow a more complete analysis of your answers.

1. What is your gender?

Female

$\square$ Male

2. Are you a direct entrant into the final year?

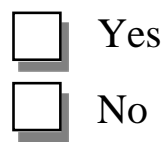

3. Did you do a work placement year last year?

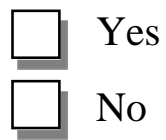

4. Is English your first language?

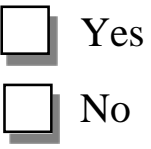

Please read each of the following statements relating to the PBL part of ABF320. You should then tick one of the subsequent boxes to indicate your response to the statement.

5. Please tick any of the following which your group found useful for communication or for collating your research for each task.

Facebook

Social bookmarking (e.g. del.icio.us)

Photo or video sharing sites (e.g. Flickr or Youtube)

Wiki documents

Word documents

Instant Messaging or texting

The group's workspace on Tulip

Other (please give details below) 
6. If your group used Facebook do you think it improved group communication?

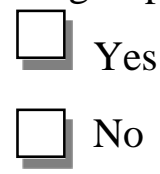

7. The timetabled PBL contact hours were weekly 2 hour sessions for this module. What do you think would be the optimum duration for the PBL sessions

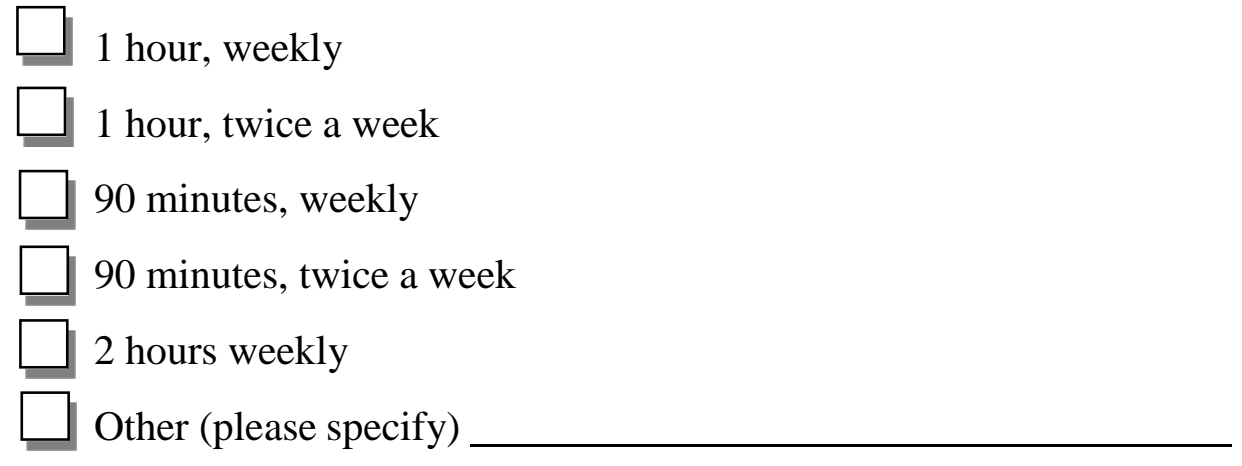

8. What size group do you think would work best for PBL?
$\square$ Less than 5
$\square$
$\square 6$
$\square 7$
8 or more

9. Our group successfully used the seven steps for each task

\begin{tabular}{|l|l|l|l|l|}
\hline Strongly agree & Agree & Neutral & Disagree & Strongly disagree \\
\hline
\end{tabular}

10. Our group became better at problem solving by the end of the PBL sessions

\begin{tabular}{|c|c|c|c|l|}
\hline Strongly agree & Agree & Neutral & Disagree & Strongly disagree \\
\hline
\end{tabular}

11. My group working skills have improved

\begin{tabular}{|l|l|l|l|l|}
\hline Strongly agree & Agree & Neutral & Disagree & Strongly disagree \\
\hline
\end{tabular}

12. Our group would have liked more support from the module leader in the contact sessions

\begin{tabular}{|l|l|l|l|l|}
\hline Strongly agree & Agree & Neutral & Disagree & Strongly disagree \\
\hline
\end{tabular}

13. I learnt more by working through the PBL process than from lectures and tutorials or seminars

\begin{tabular}{|c|c|c|c|c|}
\hline Strongly agree & Agree & Neutral & Disagree & Strongly disagree \\
\hline
\end{tabular}


14. The scenarios were authentic and sufficiently complex that a group was needed to complete the tasks

\begin{tabular}{|l|l|l|l|l|}
\hline Strongly agree & Agree & Neutral & Disagree & Strongly disagree \\
\hline
\end{tabular}

15. The scenarios stimulated learning about sustainability

\begin{tabular}{|l|l|l|l|l|}
\hline Strongly agree & Agree & Neutral & Disagree & Strongly disagree \\
\hline
\end{tabular}

16. I found the introduction to group work session helpful

\begin{tabular}{|l|l|l|l|l|}
\hline Strongly agree & Agree & Neutral & Disagree & Strongly disagree \\
\hline
\end{tabular}

17. Some members of my group dominated the group more than others.

\begin{tabular}{|l|l|l|l|l|}
\hline Strongly agree & Agree & Neutral & Disagree & Strongly disagree \\
\hline
\end{tabular}

18. Some members of my group participated less than others.

\begin{tabular}{|l|l|l|l|l|}
\hline Strongly agree & Agree & Neutral & Disagree & Strongly disagree \\
\hline
\end{tabular}

19. The level of participation of other students affected my learning experience adversely.

\begin{tabular}{|l|l|l|l|l|}
\hline Strongly agree & Agree & Neutral & Disagree & Strongly disagree \\
\hline
\end{tabular}

20. The peer review process helped to encourage participation by all group members

\begin{tabular}{|l|l|l|l|l|}
\hline Strongly agree & Agree & Neutral & Disagree & Strongly disagree \\
\hline
\end{tabular}

21. The final peer review mark reflected my contribution to the group and PBL tasks

\begin{tabular}{|l|l|l|l|l|}
\hline Strongly agree & Agree & Neutral & Disagree & Strongly disagree \\
\hline
\end{tabular}

22. For group work I feel it is important to reflect individual contribution in the final mark

\begin{tabular}{|l|l|l|l|l|}
\hline Strongly agree & Agree & Neutral & Disagree & Strongly disagree \\
\hline
\end{tabular}

23. Our group experienced conflict

$\square$ Yes, please continue to question 24
$\square$ No, please go to question 26

24. Our group resolved the conflict satisfactorily

\begin{tabular}{|c|c|c|c|l|}
\hline Strongly agree & Agree & Neutral & Disagree & Strongly disagree \\
\hline
\end{tabular}


25. The group contract was useful in resolving conflict and discouraging non-participation

\begin{tabular}{|l|l|l|l|l|}
\hline Strongly agree & Agree & Neutral & Disagree & Strongly disagree \\
\hline
\end{tabular}

26. In what way did non-participation by other members of the group affect your learning experience? Please indicate whether it was non-attendance or non-participation that was the problem.

27. What features of the PBL process do you think were most successful?

28. What features of the PBL process do you think were least successful?

29. What motivated you to contribute to the PBL process?

(You may tick more than one box)

Desire not to let the other members of the group down

Personal desire to perform well

Tutor comments and feedback

The marks from the summative assignments

The marks from the formative assignments

The peer review by all other group members

I was interested in the module content

I found the tasks engaging

I wasn't motivated to contribute

Other (please specify)

30. One of the main reasons for using PBL on this module was to promote the development of certain skills. Which of the following skills do you feel have improved as a result of participating in PBL? 
(You may tick more than one box)

Research skills

Critical analysis

Problem solving

Report writing

Presentation skills

Communication skills

Organisation skills

Time management

Group working skills

Other (please specify)

31. I had a strong sense of what the term 'sustainability' meant at the start of the module

\begin{tabular}{|l|l|l|l|l|}
\hline Strongly agree & Agree & Neutral & Disagree & Strongly disagree \\
\hline
\end{tabular}

32. By the end of the module my views on sustainability had changed

\begin{tabular}{|l|l|l|l|l|}
\hline Strongly agree & Agree & Neutral & Disagree & Strongly disagree \\
\hline
\end{tabular}

33. I found that some of the material presented/researched during the module challenged my views of the role of accounting and sustainability

\begin{tabular}{|c|c|c|c|l|}
\hline Strongly agree & Agree & Neutral & Disagree & Strongly disagree \\
\hline
\end{tabular}

34. The topics covered by PBL are listed below. Please tick those which you feel you have achieved a good understanding of as a result of the PBL process.

(You may tick more than one box)

$\square$ History of accounting for sustainability and theoretical foundations

$\square$ Globalisation and sustainability

$\square$ The limitations of traditional accounting theory and practice in promoting transparency and accountability and the role of narrative reporting

Sustainability reporting including recent developments, rationale and current reporting frameworks

Regulation of sustainability

Stakeholder engagement and dialogue

The business case for sustainability reporting 
35. The term 'sustainability' has many definitions. Which of the following reflect your view of the term 'sustainability'?

(You may tick more than one box)

$\square$ Living within the limited resources available to us

Recognising that social, environmental, economic, and political systems are inter-dependent

Equitable distribution of resources and opportunities

Respect individual rights and community responsibilities

Weigh costs and benefits of decisions fully, including long-term costs and benefits to future generations

An acknowledgement that resources are finite and that there are limits to growth

Climate change and global warming

36. Please read each of the following three descriptions relating to the delivery this module. If you could choose one of these formats which one would you prefer?

All PBL no lectures

PBL (and some guest lectures) for a period of time then lectures and workshops for period of time

PBL with guest lectures running alongside as a resource over both terms

All lectures no PBL

THANK YOU FOR COMPLETING THIS QUESTIONNAIRE 
Appendix 3

(Table 3 here) 


\begin{tabular}{|c|c|c|}
\hline Scenario & Group role and task & Theme and rationale for inclusion in module \\
\hline Practice & $\begin{array}{l}\text { As educational advisors } \\
\text { specialising in Education } \\
\text { for Sustainable } \\
\text { Development, produce a } \\
\text { Sustainability/Sustainable } \\
\text { Development wiki for a } \\
\text { group of first year Business } \\
\text { School students. }\end{array}$ & $\begin{array}{l}\text { What is Sustainability \& Sustainable } \\
\text { Development? } \\
\text { - Introduction to the topic, chance to explore } \\
\text { variety of meanings to these terms, building } \\
\text { on prior knowledge or assumptions about } \\
\text { sustainability } \\
\text { - Introduce the idea of 'wicked' problems } \\
\text { (audio extract which explores whether } \\
\text { sustainable development can exist or is it an } \\
\text { oxymoron? Range of views, no 'right' or } \\
\text { 'wrong') } \\
\text { - Develop 'critical thinking' and team working } \\
\text { through wiki output }\end{array}$ \\
\hline 1 & $\begin{array}{l}\text { As newly appointed } \\
\text { advisors to Global Imports } \\
\text { Plc., prepare a short } 10 \\
\text { minute presentation to the } \\
\text { board of directors to present } \\
\text { the case for the introduction } \\
\text { of sustainability reporting } \\
\text { to the company. } \\
\text { (10\% assessment } \\
\text { weighting) }\end{array}$ & $\begin{array}{l}\text { Rationales for Sustainability Reporting: } \\
\text { Legitimacy \& voluntary corporate reporting } \\
\text { - Why businesses should 'account for } \\
\text { sustainability' with consideration of three } \\
\text { strands (environmental, ethical and } \\
\text { economic) } \\
\text { - Link to Management Accounting through } \\
\text { ideas of circular economy } \\
\text { - Critically assess developments and rationales } \\
\text { for sustainability accounting, drawing on } \\
\text { knowledge of the theoretical foundations, } \\
\text { current practice and recent developments in } \\
\text { accounting for sustainability }\end{array}$ \\
\hline 2 & $\begin{array}{l}\text { As a researcher in Cornix } \\
\text { Plc, produce a timeline and } \\
\text { report of the history and } \\
\text { trends of sustainability } \\
\text { reporting for the head of the } \\
\text { company's research } \\
\text { department. } \\
\text { (10\% assessment } \\
\text { weighting) }\end{array}$ & $\begin{array}{l}\text { Historical Perspectives of Sustainability } \\
\text { Reporting: History \& standardisation of } \\
\text { sustainability reporting } \\
\text { - Setting the scene from early 'environmental } \\
\text { roots' through to the inclusion of social and } \\
\text { ethical practises } \\
\text { - Consideration of why there has been a } \\
\text { growth in knowledge and interest in } \\
\text { sustainability linking it to 'world events' } \\
\text { (timeline part of assessment which also } \\
\text { encourages analysis rather than repeat } \\
\text { research) } \\
\text { - What is the history of sustainability? } \\
\text { - What should sustainability reports contain? } \\
\text { How has this changed over time? }\end{array}$ \\
\hline
\end{tabular}




\begin{tabular}{|c|c|c|}
\hline & & $\begin{array}{l}\text { Evaluate developments in mandatory } \\
\text { regulation of social and environmental } \\
\text { accounting (UK context) }\end{array}$ \\
\hline 3 & $\begin{array}{l}\text { As a team of investment } \\
\text { analysts working for } \\
\text { Pyramid Investments } \\
\text { providing advice to } \\
\text { investors and companies, } \\
\text { give a } 15 \text { minute } \\
\text { presentation to a group of } \\
\text { potential investors. Provide } \\
\text { further information about } \\
\text { the issues around socially } \\
\text { responsible investments } \\
\text { (SRI) and address their } \\
\text { concerns about the relative } \\
\text { risks of SRIs. } \\
\text { (10\% assessment } \\
\text { weighting) }\end{array}$ & $\begin{array}{l}\text { Sustainability Reporting: Standards, codes } \\
\text { and stakeholders } \\
\text { - } \quad \text { Sustainability reporting in practise, a look at } \\
\text { 'real life' accounts } \\
\text { - How are sustainability reports presented } \\
\text { (online, hard copy, how growth in online } \\
\text { reporting has led to a proliferation of } \\
\text { reporting) } \\
\text { - Link to Financial Reporting topic } \\
\text { - Evaluation of developments in mandatory } \\
\text { regulation of social and environmental } \\
\text { accounting } \\
\text { - Discussion of limitations of traditional } \\
\text { accounting theory and practice in promoting } \\
\text { transparency and accountability } \\
\text { Critical evaluation of effectiveness of } \\
\text { different sustainable accounting models and } \\
\text { techniques }\end{array}$ \\
\hline 4 & $\begin{array}{l}\text { As a team of advisors } \\
\text { working for a leading } \\
\text { international accountancy } \\
\text { firm providing } \\
\text { sustainability services to } \\
\text { corporate clients, produce a } \\
\text { report for the board of } \\
\text { directors of Matrose Plc, } \\
\text { explaining how to develop } \\
\text { their sustainability } \\
\text { reporting and improve their } \\
\text { 'sustainability' rating. } \\
\text { (10\% assessment } \\
\text { weighting) }\end{array}$ & $\begin{array}{l}\text { Sustainable and Ethical Investment: Green \& } \\
\text { ethical investment funds and indices } \\
\text { - Green Investment Funds, Audit and } \\
\text { Assurance, Green Finance Initiatives } \\
\text { - } \quad \text { Risk and reporting } \\
\text { - } \quad \text { Link to Financial Management and Audit } \\
\text { topics }\end{array}$ \\
\hline
\end{tabular}

Table 1: PBL scenarios: group roles, tasks, themes, and rationale for inclusion in module (inspired by Hopwood, et al, 2010 and Unerman, et al, 2007)

\begin{tabular}{|l|l|}
\hline $\begin{array}{l}\text { Student } \\
\text { interviews }\end{array}$ & Student demographic \\
\hline S1 & $\begin{array}{l}\text { Male, white British, medium } \\
\text { ability. }\end{array}$ \\
\hline S2 & Male, white British, high ability. \\
\hline S3 & Male, Chinese, medium ability. \\
\hline S4 & Female, white British, high ability. \\
\hline
\end{tabular}




\begin{tabular}{|l|l|}
\hline S5 & $\begin{array}{l}\text { Female, white British, medium } \\
\text { ability. }\end{array}$ \\
\hline S6 & $\begin{array}{l}\text { Male, British Asian, medium } \\
\text { ability. }\end{array}$ \\
\hline
\end{tabular}

Table 2: Coding system employed

Inclusion of specific learning outcome on group work

Structured approach to group work

Careful selection of groups by module leader

\section{Requirement to write group contract}

\section{Facilitation of group work}

\section{Peer assessment}

Reflective essay $(60 \%$ final assessment)
Conveys importance of group work to students by including it as an element of assessment criteria

Use of Maastricht 7 step or 'jump' approach to problembased learning (after Gijselaers, et al, (1995) - entailed clarifying concepts, defining the problem, analysing the problem/brainstorming, categorizing, formulating research questions, independent study, and collective discussion of newly acquired knowledge.

Module leader selected group before start of module. Five to six members per group ( $71 \%$ students surveyed believed this was optimal number). Mix of abilities, ethnicities, gender, work experience

Groups were tasked with writing their own set of group rules in a 'contract' to which they all committed to adhere (75\% students said group contract had been useful in resolving conflict and discouraging non-participation).

Provision of module handbook detailing PBL process and Belbin's team roles. Extra staff support for reflective essay component of assessment.

Use of Online Peer Assessment System (OPAS) to ensure fairer allocation of individual marks within group-assessed outputs of presentations and reports. $67 \%$ students said OPAS had positively affected levels of participation and $76 \%$ agreed that final adjusted mark for group collaboration adequately reflected level of contribution made by individual.

Inclusion of essay to enable students to reflect on their contribution to the group work activities and to evaluate their understanding of sustainability.

Table 3: Facilitation, support, and assessment for effective group work 